\title{
PROFIL KETERLIBATAN ORANG TUA DALAM PENDIDIKAN ANAK USIA TK
}

\author{
Mukti Amini \\ email: muktiamini@ut.ac.id \\ Pendidikan Anak Usia Dini, Universitas Terbuka \\ Jl. Cabe Raya, Pondok Cabe Pamulang, Tangerang Selatan 15418
}

\begin{abstract}
Abstrak: Penelitian ini bertujuan untuk mendapatkan gambaran data demografis (pendidikan dan pekerjaan) orangtua anak usia TK, keterlibatan orangtua dalam kegiatan di TK, dan keterlibatan orangtua dalam mendidik anak di rumah, di Tangerang Selatan. Penelitian ini bersifat eksploratif dengan analisis deskriptif. Penelitian dilakukan pada tahun ajaran 2013/2014 di TK yang berada di Tangerang Selatan. Subjek penelitian berjumlah 238 orang. Hasil penelitian menunjukkan, dari sisi pendidikan dan pekerjaan, orangtua cukup berpotensi untuk banyak terlibat dalam pengasuhan anak. Keterlibatan orangtua baik di TK maupun di rumah sudah cukup baik, namun perlu ditingkatkan khususnya dalam melatih kemandirian keseharian anak di rumah dan kesediaan menjadi relawan di TK. Oleh karena itu perlu dipikirkan strategi yang sesuai agar orangtua lebih terlibat dalam pendidikan anaknya.
\end{abstract}

Kata-kata kunci: keterlibatan orang tua, pendidikan anak, taman kanak-kanak

\section{PROFILE OF PARENTS INVOLVEMENT IN THE EDUCATION OF THE CHILDREN OF KINDERGARTEN AGE}

\begin{abstract}
This study aimed at obtaining an overview of demographic data (education and employment) of the parents of kindergarten children, the parental involvement in the kindergarten activities and in educating their children at home. As an exploratory research with descriptive analysis, the study was conducted in the school year of 2013/2014 in Pamulang and Serpong, Sub District of South Tangerang, Banten, where 238 parents were participaed as the subjects of the research. The finding of the research showed, in terms of education and employment many parents are potential enough to take part in child care. The involvement of both parents both in the kindergarten and at home is pretty good, but needs to be improved, especially in educating their children at home everyday to be independent. The parents are also needed to persuade to be volunteers in the kindergarten. Therefore, further research is recommended to identify appropriate strategies to make the parents more involved in their children's education.
\end{abstract}

Keywords : parental involvement, child education, kindergarten

\section{PENDAHULUAN}

Pendidikan anak secara formal memang berlangsung di lembaga-lembaga PAUD seperti Pos PAUD, Kelompok Bermain (KB) Taman Penitipan Anak (TPA) dan Taman kanak-kanak (TK). Namun di samping pendidikan secara formal, pendidikan anak usia dini juga dapat dilangsungkan secara informal, yaitu pendidikan yang dilakukan oleh orang tua kepada anaknya. Semestinya, pendidikan informal dengan pendidikan formal yang dialami anak akan berjalan seiring sejalan.

Orangtua bertanggung jawab terhadap keberhasilan pendidikan anaknya, karena (1) anak adalah anugerah Tuhan kepada orangtua, (2) anak mendapat pendidikan pertama dari orang tua (3) orangtua lah yang mengetahui karakter anaknya (Graha, 2007). Pentingnya keterlibatan orangtua antara lain dikemukakan oleh Bronfenbrenner (1976) dalam Morrison (2008) yang menyatakan bahwa tanpa keterlibatan keluarga, intervensi program pendidikan anak usia dini akan melemah. Penelitian lain menyatakan bahwa orangtua yang terlibat dalam pengasuhan anak yang bersekolah TK akan mempererat hubungan dengan anak, mendapatkan tambahan pengetahuan dari TK ketika mengikuti kegiatan rutin, dan dapat menerapkan ilmu pengetahuan baru yang dimiliki tersebut pada 
anak (Retnaningtyas, 2015).

Namun kadang hambatan dalam pendidikan

di TK justru datang dari pihak orangtua, antara lain ditunjukkan dengan rendahnya keterlibatan orangtua dalam pengasuhan anak. Penelitian Fardana \& Tairas (2012) di PAUD pedesaan wilayah Kab. Gresik menyimpulkan bahwa relasi orang tuaanak di rumah kurang berorientasi pada konsep belajar melalui bermain. Sementara itu, relasi orang tua-anak masih bersandar pada pengalaman individual orang tua dan tata cara pengasuhan yang diwariskan keluarga.

Berdasarkan pengamatan pendahuluan di TK Al-Hikmah, Tangerang Selatan, ternyata berapa orangtua menuntut agar anaknya dapat membaca menulis dan berhitung (calistung) selama belajar di TK, dan tuntutan ini dibebankan kepada guru TK, sementara stimulasi calistung dari orangtua justru sangat kurang. Berdasarkan wawancara dengan para guru di TK tersebut, terdapat 2 orang tua di kelompok $\mathrm{B}$ (dari 30 orang tua) yang sering meminta pekerjaan rumah membaca-menulis-berhitung (ca-listung), sedang di kelompok $A$ ada 1 dari 23 orang tua anak yang sering meminta hal serupa. Selain itu, kadang orang tua tidak melanjutkan pembiasaan-pembiasaan baik yang sudah diawali di TK. Mi-salnya, di TK anak diajarkan untuk selalu berdoa sebelum dan sesudah makan atau mencuci tangan, tetapi di rumah kebiasaan ini tak diajarkan lagi. Juga dalam hal menunggu antrian, mencontohkan berbicara santun, dan sebagainya, kadang tidak menjadi perhatian orang tua saat anak berada di rumah.

Guru dapat mengetahui keterlibatan orangtua berdasarkan cerita anak dan perilaku anak di TK. Berdasarkan wawancara dengan guru di TK Al-Hikmah, mereka mengeluhkan tentang kurangnya ke-terlibatan orangtua dalam melanjutkan pembiasaan baik ini, yaitu: di kelompok A ada 3 (dari 23 orang tua), dan di kelompok $B$ ada 7 orang tua (dari 30 orang), dan di Play Grup ada 2 (dari 14 orang tua). Berdasarkan wawancara dengan para guru TK di Tangerang Selatan, masalah-masalah serupa juga mereka alami.

Berdasarkan latar belakang di atas, perlu dilihat tentang keterlibatan orang tua dalam mendidik anak di rumah dan di TK, serta data demografis orangtua berupa pendidikan dan pekerjaan mereka. Jadi tujuan diadakannya penelitian ini adalah untuk mendapatkan gambaran tentang:
(1) data demografis (pendidikan dan pekerjaan) orangtua anak usia TK, (2) keterlibatan orangtua dalam kegiatan di TK, dan (3) keterlibatan orangtua dalam mendidik anak di rumah maupun di TK di wilayah Tangerang Selatan. Tulisan ini diharapkan bermanfaat bagi: para orang tua di TK, sebagai masukan terhadap cara mengasuh dan mendidik anak sesuai tugas perkembangannya dan guru-guru TK, sebagai upaya penambahan wawasan tentang bentuk kegiatan kerja sama dengan orang tua yang aplikatif dan langsung dapat dirasakan manfaatnya.

Orang tua memiliki peran yang sangat penting dalam pendidikan anak. Peran orang tua bagi pendidikan anak, antara lain adalah: (1) guru pertama dan utama bagi anak, (2) anak belajar kehidupan dan belajar mengembangkan seluruh aspek pri-badinya, (3) pelindung utama bagi anak, (4) sumber kehidupan bagi anak, (5) tempat bergantung anak, dan (6) sumber kebahagiaan anak (http://paudust.blogspot.com). Berdasarkan pendapat tersebut, terlihat jelas bahwa orang tua terutama ibu, yang lebih banyak bersama anak sejak bayi, menjadi tokoh sentral dalam upaya pengembangan minat dan bakat anak. Lebih jauh, Arya (2008) menjelaskan bahwa peran orang tua dalam memotivasi bakat dan minat anak dapat dilakukan dengan cara: (1) me-ngajarkan anak untuk mengharapkan keberhasilan, (2) menyesuaikan pendidikan anak dengan minat dan gaya belajarnya, (3) anak harus belajar bahwa diperlukan keuletan untuk mencapai keberhasilan, dan (4) anak harus belajar bertanggung jawab dan belajar menghadapi kegagalan.

Selain itu, menurut Iskaradah (2009), orang tua juga berperan dalam pengembangan anak yang meliputi: (1) memelihara kesehatan fisik dan mental anak, (2) meletakkan dasar kepribadian yang baik, (3) membimbing dan memotivasi anak untuk mengembangkan diri, (4) memberikan fasilitas yang memadai bagi pengembangan diri anak, dan (5) menciptakan suasana yang aman, nyaman dan kondusif bagi pengembangan anak. Berdasarkan pendapat Iskaradah tersebut terlihat bahwa peran orang tua sangat fundamental, tidak hanya dalam pendidikan tetapi juga pertumbuhan dan perkembangan anak.

Secara teknis, Hayati (2011) membagi sikap orang tua yang menunjang pengembangan potensi anak dengan yang menghambat potensinya. Sikap orang tua yang menunjang potensi anak 
dapat dilihat dari: (1) menghargai pendapat anak dan mendorongnya untuk mengungkapkannya, (2) memberi waktu kepada anak untuk berpikir, merenung, dan berkhayal, (3) membolehkan anak untuk mengambil keputusan sendiri, (4) mendorong anak untuk ba-nyak bertanya, (5) meyakinkan anak bahwa orangtua menghargai apa yang ingin dicoba, dilakukan dan dihasilkan (6) menunjang dan mendorong kegiatan anak, (7) menikmati keberadaannya bersama anak, (8) memberi pujian yang sungguh-sungguh kepada anak, (9) mendorong kemandirian anak dalam bekerja dan (10) menjalin hubungan kerja sama yang baik dengan anak.

Sedang sikap orang tua yang menghambat potensi anak antara lain adalah: (1) mengatakan kepada anak bahwa ia dihukum jika berbuat salah, (2) tidak membolehkan anak marah kepada orangtua (3) tidak boleh menanyakan keputusan orangtua, (4) tidak membolehkan anak bermain dengan anak lain yang mempunyai pandangan dan nilai yang berbeda dari keluarga anak, (5) anak tidak boleh berisik, (6) orang tua ketat mengawasi kegiatan anak, (7) orang tua tidak memberi saransaran yang spesifik tentang penyelesaian tugas, (8) orang tua kritis terhadap anak dan menolak gagasan anak, (9) orang tua tidak sabar dengan anak (10) orangtua dengan anak adu kekuasaan, serta (11) orangtua menekan dan memaksa anak untuk menyelesaikan tugas.

Batasan keterlibatan orangtua antara lain partisipasi orang tua dalam proses pendidikan dan pengalaman bagi anak mereka, meliputi keterlibatan orang tua berbasis di rumah, misalnya menyimak anak-anak membaca atau memeriksa PR-nya. Juga termasuk keterlibatan orangtua di sekolah, seperti kesertaan orang tua dalam seminar pendidikan dan pertemuan antara orang tua-guru (Jeynes, 2005 dalam Hornby, 2011). Keterlibatan orang tua dapat meliputi: memelihara arah kemajuan anak, sering berkomunikasi dengan guru, memastikan bahwa anak-anak menikmati tantangan, kelas pembelajaran yang baik, mengarahkan anak untuk memiliki motivasi berprestasi tinggi di sekolah (Hill \& Taylor, 2004 dalam Berk, 2006).

Berkaitan dengan dampak keterlibatan orangtua, penelitian dari Henderson dan Mapp (2002), menyatakan bahwa terkait keterlibatan orang tua dengan kualitas sekolah, ada dua butir simpulan penelitian sebagai berikut: (1) sekolah yang bekerja sama baik dengan orangtua menunjukkan semangat guru yang meningkat, dan mendapat penilaian yang lebih tinggi dari para orang tua, (2) sekolah yang para orang tuanya terlibat memiliki dukungan yang lebih banyak dan memiliki reputasi yang lebih baik di masyarakat. Mereka juga menyatakan bahwa keterlibatan orangtua dalam pendidikan anak berhubungan dengan prestasi anak, perilaku anak, budaya, usia, dan kualitas sekolah. Dalam hal prestasi untuk anak usia dini, pengaruh keterlibatan orang tua bisa dilihat dari beberapa hasil penelitian berikut: (1) ketika orang tua terlibat - tanpa melihat status sosial ekonomi, latar belakang etnis/ras atau tingkat pendidikan orangtua -, anak-anak akan menunjukkan prestasi yang lebih tinggi, (2) ketika orang tua terlibat dalam pendidikan anaknya, anak akan lebih sering membantu pekerjaan rumah, dan lebih tinggi dalam kehadiran di sekolah, (3) dalam program yang dirancang untuk melibatkan orang tua dalam kemitraan yang penuh, prestasi anak dari keluarga yang tidak beruntung tidak hanya meningkat tetapi juga mampu mencapai level standar seperti yang dipersyaratkan bagi anak dari keluarga status sosial ekonomi menengah, serta (4) anak kemungkinan besar akan mengalami kemunduran prestasi jika orang tua tidak berpartisipasi dalam kegiatankegiatan sekolah, tidak mengembangkan hubungan yang menguntungkan dengan guru, dan tidak memantau apa yang terjadi di sekolah anaknya.

Dalam hal perilaku untuk anak usia dini, pengaruh keterlibatan orang tua dalam pendidikan anak bisa dilihat dari hasil penelitian berikut: (1) ketika anak bercerita bahwa dia merasa mendapat dukungan dari sekolah dan rumah, anak akan memiliki kepercayaan diri yang lebih tinggi, menganggap sekolah lebih penting, dan cenderung melakukan sesuatu dengan lebih baik, (2) perilaku kekerasan dan antisosial dari anak menunjukkan penurunan seiring dengan meningkatnya keterlibatan orangtua, dan (3) anakanak memperlihatkan sikap dan perilaku yang lebih positif saat orang tua terlibat aktif.

Sementara itu, Epstein (1995) mengidentifikasi enam tipe keterlibatan orangtua dan strategi yang dapat dilakukan guru untuk mengembangkan kerjasama dengan orang tua. Enam tipe tersebut adalah tugas keorangtuaan (parenting), komunikasi (communicating), relawan (volunteering), belajar di rumah (learning at home), pengambil keputusan 
(decision making), dan kerja sama dengan masyarakat (collaborating with community). Penelitian dari Irsyadi (2012) menyimpulkan bahwa semakin baik pola asuh orang tua, maka semakin tinggi pula tingkat kemandirian anak. Sementara itu, penelitian Fardana dan Tairas (2012) menyatakan bahwa relasi orang tua-anak di rumah kurang berorientasi pada konsep belajar melalui bermain, dan relasi antara orang tua-guru TK terkendala oleh keyakinan bahwa guru adalah pemegang otoritas pendidikan PAUD sehingga orangtua tidak perlu melibatkan diri mengkomunikasikan berbagai hal yang terkait dengan pendidikan anak..

Berdasarkan paparan tersebut terlihat bahwa melalui keterlibatan orang tua yang intensif terhadap tumbuh kembang anak, banyak pengaruh positif yang diperoleh anak. Sebaliknya, kurangnya keterlibatan orang tua akan mengakibatkan berbagai pengaruh buruk seperti menurunnya prestasi, meningkatnya perilaku antisosial, dan hubungan yang kurang baik dengan guru dan orang tua.

Keterlibatan orangtua dalam pendidikan anaknya dapat dipengaruhi oleh berbagai faktor, antara lain pendidikan dan pekerjaan orangtua dan. Davis-Kean (2005) menyatakan bahwa tingkat pendidikan orangtua berhubungan dengan keterlibatan orangtua dalam pendidikan dan pengasuhan anak. Menurutnya, pendidikan orangtua secara tidak langsung dapat memengaruhi pencapaian akademis anak karena adanya dukungan kepercayaan orangtua dan perilaku yang merangsang pendidikan di rumah. Pendidikan orangtua dapat berperan penting karena selama waktu-waktu tersebut, selain anak menempuh pendidikan di sekolah, orangtua juga dapat berperan sebagai 'guru' di rumah. Orangtua dapat menjadi guru yang efektif karena mereka banyak mengetahui tentang apa yang diperkirakan sedang diajarkan oleh sekolah, serta apa yang perlu mereka lakukan sebagai lanjutannya di rumah. Orangtua juga dapat membantu anak mengerjakan pekerjaan rumah dan menyediakan dukungan stimulasi kognitif di rumah.

Pendapat Davis-Kean dikuatkan oleh Hoffman dan Lipit (dalam Mussen, 1970) yang menjelaskan bahwa pola asuh orangtua antara lain dipengaruhi oleh tingkat pendiddikan orangtua. Apakah orangtua memiliki tingkat pendidikan yang tinggi atau tingkat pendidikan yang rendah akan memengaruhi mereka dalam mengasuh anakanaknya. Wong (2009) juga menguatkan pendapat sebelumnya. Dia menyatakan salah satu faktor yang memengaruhi pengasuhan adalah pendidikan dan pengalaman orangtua. Pendidikan dan pengalaman orangtua dalam merawat anak akan memengaruhi kesiapan mereka dalam menjalankan tugas keorangtuaan.

Davis-Kean juga melihat pekerjaan orangtua sebagai salah satu faktor yang memengaruhi keterlibatan orangtua dalam pengasuhan anak. la menyatakan bahwa orangtua dengan pemasukan ekonomi menengah ke atas dan dengan berlatar belakang pendidikan memiliki keyakinan dan harapan yang lebih realistis dengan performa anak-anak mereka di sekolah dibandingkan dengan keluarga yang memiliki pemasukan ekonomi rendah. Keluarga dengan pemasukan ekonomi rendah juga memiliki keyakinan dan harapan yang tinggi, tetapi tidak berkorelasi baik dengan performa anak-anak mereka di sekolah.

Kemampuan orangtua dalam membentuk keyakinan dan harapan yang sesuai berdasarkan performa anak-anak mereka sangat penting untuk mendukung lingkungan rumah dan pendidikan yang kondusif, sehingga mereka dapat berusaha lebih baik di luar lingkungan sekolahnya. Hubungan tidak langsung ini memberikan pengaruh melalui ekspektasi pendidikan, perilaku membaca, bermain, serta afektif orangtua. Sementara itu, hasil penelitian lain menyimpulkan bahwa pada keluarga dengan pemasukan dari pekerjaan yang rendah, keluargakeluarga tersebut mengalami ketidakstabilan kondisi dan status seperti stress, perpindahan, perubahan status kerja, dan sekolah anak yang berpindahpindah), yang pada gilirannya akan memengaruhi keterlibatan orangtua pada sekolah anak-anak mereka (Englund dkk., 2004).

Sementara itu Sanderson \& Thompson (2002) menyatakan bahwa salah satu yang memengaruhi pola asuh orangtua adalah status pekerjaan orangtua. Status pekerjaan menentukan cara orangtua dalam mengasuh anaknya. Lingkungan pekerjaan dimana individu-individu yang telah berkeluarga dan memilki anak, biasanya saling bertukar pengalaman mengenai kondisi keluarga. Individu yang sukses menata keluarganya termasuk bagaimana mengasuh anak, biasanya individu lain ingin mengikuti cara tersebut dangan maksud salah satunya adalah supaya dianggap sebagai orangtua yang berhasil. 


\section{METODE PENELITIAN}

Penelitian ini merupakan penelitian kuantitatif yang menggunakan metode exploratory research. Metode ini digunakan untuk mendapatkan gambaran (deskripsi) dari kondisi subjek penelitian.

Populasi penelitian ini adalah para orangtua dari anak 4-6 tahun yang menyekolahkan anaknya di TK yang berada di wilayah Selatan Kota Tangerang Selatan, yaitu Kecamatan Pamulang dan Serpong. Wilayah ini dipilih dengan pertimbangan di kawasan ini terdapat banyak TK baru menyesuaikan dengan pertumbuhan perumahan-perumahan baru di daerah pinggiran Jakarta yang umumnya dihuni keluarga muda. Sampel penelitian dilakukan dengan purposive random sampling yang representatif terhadap populasi penellitian. Waktu penelitian adalah tahun ajaran 2013/2014. Karakteristik subjek penelitian adalah: (1) orangtua yang memiliki anak usia 4-6 tahun, (2) mempercayakan anaknya di salah satu TK di Tangerang Selatan, (3) pendidikan minimal lulus SD, (4) mampu berkomunikasi dengan baik secara lisan dan tulisan.
Penelitian ini menggunakan instrumen berupa kuesioner tentang keterlibatan orangtua yang dilihat dari tiga hal: data demografis (pendidikan dan pekerjaan orangtua), keterlibatan orangtua di TK, dan keterlibatan orangtua di rumah. Kisi-kisi instrumen disusun dengan mengacu pada dua bentuk keterlibatan menurut Jeynes (di rumah dan di sekolah), yang dipadukan dengan empat tipe dari model Epstein yaitu: tipe komunikasi dan tipe relawan untuk keterlibatan di TK, serta tipe tugas keorangtuaan dan tipe komunikasi untuk keterlibatan orangtua di rumah. Instrumen telah diuji validitas dan reliabilitasnya. Uji validitas dilakukan dengan Pearson (Product Moment) dengan $r$ tabel 0,361. Sedang uji reliabilitas dilakukan dengan alpha Cronbach, yang menghasilkan koefisien reliabilitas sebesar 0,926. Artinya, reliabilitas instrumen sudah sangat tinggi untuk digunakan. Data yang diperoleh di lapangan disajikan secara deskkriptif dalam bentuk tabel, grafik dan analisis kualitatif.

\section{HASIL DAN PEMBAHASAN}

Penelitian ini menghasilkan data tentang data demografis orangtua (pekerjaan dan pendidikan) orangtua, keterlibatan orang tua di TK, dan keterlibatan orangtua dalam pengasuhan anak di rumah. a. Pekerjaan dan Pendidikan Orang Tua.

Melalui pekerjaan dan pendidikan orang tua anak biasanya akan dapat terlihat kaitannya dalam mengasuh anak. Jika dilihat dari status pekerjaan orang tua, maka hasilnya dapat dilihat pada tabel 1.

Tabel 1. Status dan Jenis Pekerjaan Ayah Ibu

\begin{tabular}{|c|c|c|c|c|c|c|c|c|c|c|}
\hline \multirow{2}{*}{ No } & \multirow{2}{*}{ Orangtua } & \multirow{2}{*}{$\begin{array}{c}\text { Bekerja } \\
(\%)\end{array}$} & \multicolumn{8}{|c|}{ Jenis Pekerjaan (\%) } \\
\hline & & & PS & PNS & GD & TNI & $\mathbf{W}$ & BN & IRT & LL \\
\hline 1 & Ayah & 96,64 & 51,7 & 8,4 & 0,8 & 3,4 & 24,4 & 2,1 & 0 & 8 \\
\hline 2 & Ibu & 44,54 & 20,2 & 5,5 & 7,1 & 0,8 & 12,2 & 0,4 & 51,7 & 2,1 \\
\hline \multicolumn{11}{|l|}{ Ket: } \\
\hline \multicolumn{3}{|c|}{$\mathrm{PS}=$ pegawai swasta } & \multicolumn{2}{|c|}{$\mathrm{GD}=$ guru/dosen } & \multicolumn{3}{|c|}{$\mathrm{W}=$ wiraswasta } & \multicolumn{2}{|c|}{ IRT= ibu r } & . \\
\hline \multicolumn{3}{|c|}{ PNS= pegawai negeri sipil } & tentare & polri & \multicolumn{3}{|c|}{$\mathrm{BN}=$ buruh $/$ nelayan } & \multicolumn{3}{|c|}{ LL=lain-lain. } \\
\hline
\end{tabular}

Terlihat bahwa hampir semua ayah bekerja dengan persentase di atas $95 \%$, sedangkan ibu yang bekerja hampir $45 \%$. Artinya jumlah ibu yang tidak bekerja penuh waktu cukup banyak sehingga dapat diasumsikan bahwa ibu yang tidak bekerja ini memiliki kesempatan yang lebih luas untuk mengantar jemput anaknya ke TK daripada ibu yang bekerja. Berdasarkan tabel itu juga terlihat bahwa pekerjaan ayah dan ibu didominasi sebagai pegawai swasta. Ada hal yang menarik tentang pekerjaan ibu yang sebesar $2,1 \%$, karena 1 orang diantaranya menyatakan bekerja sebagai pembantu rumah tangga (PRT), dan 2 orang adalah dokter. Sedang jika dilihat dari tingkat pendidikan, diperoleh hasil seperti yang tersaji pada tabel 2 .

Tabel 2. Tingkat Pendidikan Ayah dan Ibu

\begin{tabular}{|c|c|c|c|}
\hline \multirow{2}{*}{ No } & \multirow{2}{*}{ Tingkat } & \multicolumn{2}{|c|}{ Persentase (\%) } \\
\hline & & Ayah & lbu \\
\hline 1. & SD & 4,622 & 4,622 \\
\hline 2. & SMP & 7,983 & 12,61 \\
\hline 3. & SMA & 31,09 & 31,51 \\
\hline 4. & Sarjana & 51,26 & 48,32 \\
\hline 5. & Magister & 4,622 & 2,521 \\
\hline
\end{tabular}


Data pada tabel 2 terlihat bahwa sekitar separuh responden sudah menempuh pendidikan sarjana. Jika ditambah dengan lulusan SMA, maka persentasenya sudah di atas $80 \%$. Artinya, secara pendidikan ayah dan ibu dari anak-anak yang berada di TK wilayah Tangerang Selatan ini sudah cukup memadai.

b. Keterlibatan orang tua dalam kegiatan di TK.

Pertemuan orang tua di TK biasanya banyak melibatkan ibu. Oleh karena itu perlu diketahui tentang siapa yang mengantar jemput anak setiap harinya. Aspek keterlibatan orangtua antara lain dilihat dari pihak yang mengantar jemput anak ke TK, hasilnya dapat dilihat pada gambar 1 .

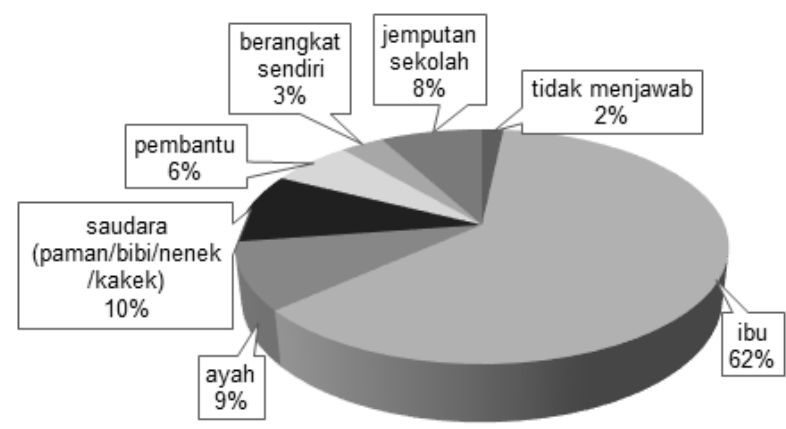

Gambar 1. Pihak yang mengantar jemput anak

Grafik pada gambar 1 memperlihatkan bahwa sebagian besar anak di antar jemput oleh ibunya sendiri. Dominasi ibu sebagai pengantar jemput anaknya ke TK diasumsikan akan memudahkan pola komunikasi antara orang tua dengan guru, sehingga perlu pula dilihat pola komunikasi orangtua di TK, yang dapat dilihat pada tabel 3 .

Tabel 3. Komunikasi Orang Tua di TK

\begin{tabular}{clc}
\hline No & \multicolumn{1}{c}{ Aspek } & $\begin{array}{c}\text { Rerata } \\
\text { (\%) }\end{array}$ \\
\hline 1 & $\begin{array}{l}\text { Berkomunikasi tentang anaknya dengan } \\
\text { guru kelas atau kepala TK }\end{array}$ & 3,32 \\
2 & Akrab dengan para orang tua anak lain di TK & 3,30 \\
3 & Terlibat dalam berbagai kegiatan di TK & 2,55 \\
4 & lkut perkumpulan kegiatan orang tua di & 2,18 \\
& kelas anak \\
\hline
\end{tabular}

Tabel 3 memperlihatkan bahwa rerata kegiatan tertinggi adalah berkomunikasi langsung dengan guru kelas anak. Sedangkan komunikasi melalui keterlibatan orang tua dalam pertemuan orang tua justru menduduki peringkat terendah, hanya 2,18 .
Artinya, partisipasi orang tua dalam pertemuan ini masih sangat perlu ditingkatkan lagi melalui kegiatan yang membuat orang tua tertarik untuk datang. Perlu pula dilihat keterbiatan orangtua dalam berbagai acara di TK yang mengundang orangtua, yang dapat dilihat pada tabel 4.

\section{Tabel 4. Keterlibatan Orang Tua dalam Kegiatan di TK}

\begin{tabular}{clc}
\hline No & \multicolumn{1}{c}{ Aspek } & $\begin{array}{c}\text { Persentase } \\
\text { (\%) }\end{array}$ \\
\hline 1 & $\begin{array}{l}\text { Acara anak dan orang tua di TK } \\
\text { (puncak tema) }\end{array}$ & 60,1 \\
2 & Forum pertemuan orang tua & 35,7 \\
3 & Seminar pendidikan & 12,2 \\
4 & Simulasi pengasuhan anak & 5,0 \\
5 & Guru sukarela & 0,4 \\
6 & Lainnya & 0,4 \\
\hline
\end{tabular}

Ternyata kegiatan pada saat puncak tema yang biasanya dihadiri oleh orang tua. Peringkat kehadiran selanjutnya adalah pada pertemuan orang tua, namun dengan persentase hampir separuhnya. Artinya, kegiatan pertemuan orang tua perlu dikemas ulang agar kehadiran orang tua dalam kegiatan tersebut cukup tinggi. Kegiatan menjadi mitra guru (guru sukarela) termasuk kegiatan yang kurang diminati dengan persentase kurang dari $1 \%$. Hal ini berhubungan dengan status dan jenis pekerjaan orangtua, karena biasanya orangtua dengan profesi tertentu lah yang memiliki kepercayaan diri cukup tinggi untuk menjadi guru sukarela atau narasumber secara insidental di kelas anaknya. Dalam hal ini, profesi orangtua seperti dokter, koki (chef), petugas pemadam kebakaran, pengelola waralaba, pemilik bengkel sepeda, dan sebagainya dapat dimanfaatkan oleh pihak TK sebagai narasumber.

c. Keterlibatan Orangtua dalam Pengasuhan Anak di Rumah.

Selain keterlibatan di sekolah anak, perlu dilihat juga keterlibatan orang tua dalam pengasuhan anak selama di rumah. Hasil penelitian menunjukkan bahwa bahwa sebagian besar orang tua memperbolehkan anak memilih mainannya sendiri, menuntun anak dalam membaca doa sehari-hari, melatih anak membereskan mainannya, melatih membereskan peralatan makan dan menemani anak saat menonton tivi. Sebagian 
besar anak sudah tidur sendiri tidak lagi bersama orang tua, namun masih banyak dibantu memakai dan melepas sepatu. Kaitannya dengan PR untuk anak, separuh orang tua masih berharap guru di TK memberikan PR untuk anaknya. Tabel 5 berikut adalah data tentang kegiatan yang dilakukan anak dan orang tua selama di rumah.

Tabel 5. Kegiatan Anak dan Orang Tua di Rumah

\begin{tabular}{|c|c|c|}
\hline No & Aspek & $\begin{array}{c}\text { Rerata } \\
(\%)\end{array}$ \\
\hline 1 & $\begin{array}{l}\text { Anda mencari pengetahuan tentang cara } \\
\text { mengasuh anak }\end{array}$ & 3,95 \\
\hline 2 & Anak menonton tivi di rumah & 3,66 \\
\hline 3 & $\begin{array}{l}\text { Anda menemani saat anak-anak menon- } \\
\text { ton tivi }\end{array}$ & 3,83 \\
\hline 4 & $\begin{array}{l}\text { Anda sempat mendongeng saat anak } \\
\text { akan tidur }\end{array}$ & 2,59 \\
\hline 5 & Anak masih dimandikan setiap harinya & 2,13 \\
\hline 6 & Anak masih tidur bersama orang tua & 1,71 \\
\hline 7 & $\begin{array}{l}\text { Anak masih disuapi jika makan setiap } \\
\text { harinya }\end{array}$ & 2,58 \\
\hline 8 & $\begin{array}{l}\text { Anak dilatih membereskan peralatan } \\
\text { makannya di rumah }\end{array}$ & 3,76 \\
\hline 9 & $\begin{array}{l}\text { Anak dituntun dalam membaca doa sehari- } \\
\text { hari di rumah }\end{array}$ & 4,13 \\
\hline 10 & $\begin{array}{l}\text { Anak masih dibantu dalam memakai dan } \\
\text { melepaskan baju }\end{array}$ & 2,51 \\
\hline 11 & $\begin{array}{l}\text { Anak masih dibantu dalam memakai } \\
\text { melepas sepatu }\end{array}$ & 3,35 \\
\hline 12 & $\begin{array}{l}\text { Anak dilatih membereskan mainannnya } \\
\text { sendiri di rumah }\end{array}$ & 4,11 \\
\hline 13 & $\begin{array}{l}\text { Anak diperbolehkan memilih mainan } \\
\text { sendiri saat membeli }\end{array}$ & 4,15 \\
\hline 14 & Anak minta dibacakan buku oleh orang tua & 3,22 \\
\hline 15 & $\begin{array}{l}\text { Orang tua menghendaki anaknya diberi- } \\
\text { kan PR dari sekolah }\end{array}$ & 2,52 \\
\hline
\end{tabular}

Selanjutnya, hasil penelitian tentang kegiatan anak sehari-hari di rumah dan intensitasnya menunjukkan bahwa menonton televisi masih menjadi kegiatan favorit anak di rumah, diikuti tidur siang, bermain, mengaji, mendengarkan cerita, dan les privat membaca. Keberadaan les privat membaca meskipun presentasinya kecil menunjukkan bahwa orang tua belum sepenuhnya memahami tentang usia bermain pada anak-anak. Demikian juga dengan les bahasa Inggris dan mengerjakan PR. Data mengenail kegiatan anak sehari-hari di rumah dapat dilihat pada tabel 6 .
Tabel 6. Kegiatan Anak Sehari-hari di Rumah

\begin{tabular}{llc}
\hline No & \multicolumn{1}{c}{ Kegiatan } & $\begin{array}{c}\text { Persentase } \\
\text { (\%) }\end{array}$ \\
\hline 1 & Menonton televisi & 85.29 \\
2 & Tidur siang & 77.73 \\
3 & Bermain dengan teman & 67.23 \\
4 & Bermain alat-alat mainnya & 66.81 \\
5 & Mengaji & 57.98 \\
6 & Bermain game elektronik dari kom- & 52.94 \\
& puter/hand phone & \\
7 & Mendengarkan cerita dari buku/VCD & 36.13 \\
8 & Les privat membaca & 16.81 \\
9 & Lainnya & 0,4 \\
\hline
\end{tabular}

Kaitannya dengan durasi anak menonton tv dan bermain game, diperoleh data seperti pada tabel 7 .

Tabel 7. Durasi Anak Menonton Televisi
dan Bermain Game

\begin{tabular}{cccccccc}
\hline & & \multicolumn{7}{c}{ Persentase (\%) } \\
\cline { 3 - 8 } No & Aspek & $\begin{array}{c}\mathbf{<} \mathbf{1} \\
\text { jam }\end{array}$ & $\begin{array}{c}\mathbf{1 - 2} \\
\text { jam }\end{array}$ & $\begin{array}{c}\mathbf{2 - 3} \\
\text { jam }\end{array}$ & $\begin{array}{c}\mathbf{3 - 4} \\
\text { jam }\end{array}$ & $\begin{array}{c}\mathbf{4 - 5} \\
\text { jam }\end{array}$ & $\begin{array}{c}\mathbf{7} \\
\text { jam }\end{array}$ \\
\hline 1 & $\begin{array}{l}\text { Menonton } \\
\text { televisi }\end{array}$ & 13.87 & 42.02 & 25.21 & 11.34 & 3.36 & 1.26 \\
2 & $\begin{array}{l}\text { Bermain } \\
\text { game }\end{array}$ & 41.18 & 22.27 & 8.403 & 2.101 & 2.10 & 0 \\
\hline
\end{tabular}

Tabel 7 memperlihatkan bahwa sebagian besar anak menonton tv setiap hari selama 1 hingga 2 jam, dan seperempat anak menonton tivi hingga 2-3 jam. Temuan ini juga menunjukkan bahwa masih ada orang tua yang membiarkan anaknya menonton tv lebih dari 4 jam meskipun persentasinya tidak banyak. Sedangkan untuk bermain game, lebih sedikit waktu yang digunakan yaitu sekitar 1 jam. Namun juga masih ada orang tua yang membiarkan anaknya bermain game hingga 4-5 jam setiap harinya. Pembiaran menonton tv atau bermain game lebih dari 4 jam setiap hari merupakan hal yang perlu menjadi perhatian untuk melihat keterlibatan orangtua dalam mengawasi kegiatan anak di rumah.

Adapun hasil penelitian sumber yang biasa diakses orang tua untuk mendapatkan pengetahuan pengasuhan anak menunjukkan bahwa 5 besar sumber informasi favorit yang banyak diakses oleh orang tua tentang pengasuhan anak berturutturut adalah dari acara tv, nasihat orang tua, buku 
pendidikan anak, majalah parenting, dan pertemuan orang tua di TK. Untuk lebih lengkapnya, data mengenai akses informai tentang pengasuhan anak dapat dilihat pada tabel 8 .

Tabel 8. Akses Informasi Tentang Pengasuhan Anak

\begin{tabular}{llc}
\hline No & \multicolumn{1}{c}{ Sumber } & $\begin{array}{c}\text { Persentase } \\
\text { (\%) }\end{array}$ \\
\hline 1 & Acara TV & 47.90 \\
2 & Nasehat orang tua & 41.18 \\
3 & Buku pendidikan anak & 34.45 \\
4 & Majalah parenting & 34.45 \\
5 & Pertemuan orang tua di TK & 31.51 \\
6 & Seminar/pelatihan pendidikan anak & 21.85 \\
7 & Kursus baby sitter & 4.622 \\
8 & PKK di lingkungan & 3.361 \\
9 & Lainnya & 17.30 \\
\hline
\end{tabular}

Selanjutnya, gambaran tentang harapan orang tua pada anak dapat dijelaskan seperti pada tabel 9.

Tabel 9. Harapan Orang Tua pada Anak

\begin{tabular}{llc}
\hline No & \multicolumn{1}{c}{ Aspek } & $\begin{array}{c}\text { Persentase } \\
\mathbf{( \% )}\end{array}$ \\
\hline 1 & Anak dapat mencapai cita-cita & 73.11 \\
2 & Anak patuh pada orang tua & 73.11 \\
3 & Anak rajin beribadah & 68.07 \\
4 & Anak sayang pada sesama & 60.92 \\
5 & Anak bahagia hidupnya & 59.24 \\
6 & Anak minimal menjadi sarjana & 30.25 \\
7 & Lainnya & 13.45 \\
\hline
\end{tabular}

Menurut Davis-Kean (2005), tingkat pendidikan orangtua berhubungan dengan keterlibatan orangtua dalam pendidikan dan pengasuhan anak. Pada hasil penelitian ini, sebagian besar orang tua adalah sarjana dan lulusan SMA. Artinya, diasumsikan orangtua memiliki minat yang tinggi dalam keterlibatan mengasuh dan mendidik anak. Penelitian Grolnic dkk (1997) dan Hornby \& Lafaele (2011) menyatakan bahwa tingkat pendapatan memiliki pengaruh terhadap keterlibatan orangtua mendidik anak. Namun pada penelitian ini memang tidak ditanyakan tentang jumlah pendapatan, hanya secara umum dapat dilihat bahwa ibu dan ayah memiliki cukup waktu dan cukup daya untuk bersama anak melakukan tugas keorangtuaan.
Penelitian ini juga memperlihatkan bahwa sebagian besar ibu statusnya tidak bekerja, sehingga diasumsikan para ibu yang tidak bekerja ini memiliki lebih banyak waktu untuk melakukan tugas keorangtuaan (parenting) sebagaimana tipe keterlibatan pertama yang dikemukakan Epstein (2002). Hal ini diperkuat dengan data bahwa ternyata sebagian besar anak memang di antar jemput oleh ibunya sendiri ke TK, sehingga dapat diasumsikan ibu memiliki kesempatan yang besar untuk terlibat dalam pendidikan anak di TK, yaitu dengan membangun komunikasi secara intensif dengan pihak TK. Hal ini sesuai dengan tipe keterlibatan orangtua yang kedua menurut Epstein (2002), yaitu komunikasi. Secara umum, komunikasi yang dilakukan para ibu tersebut adalah dengan menanyakan kondisi atau permasalahan anaknya kepada guru kelas, atau kepala TK.

Selain itu, orang tua juga menjalin hubungan yang baik dengan sesama orangtua lain di TK, sambil menunggu anak mereka pulang. Sebagian besar ibu memang memilih untuk menunggui anaknya di TK karena jadwal belajar yang tidak terlalu lama (pukul 07.30-10.00), terutama bagi para ibu yang tidak memiliki agenda atau kewajiban lain. Kadang saat menunggu ini diisi dengan saling berjualan atau arisan. Namun, komunikasi oleh para orangtua dalam kegiatan resmi atau pertemuan orangtua secara berkala yang diundang dari TK, justru tidak terlalu tinggi. Hal ini berarti kehadiran orangtua dalam berbagai kegiatan atau pertemuan orangtua di TK belum seperti yang diharapkan.

Ragam profesi orangtua yang bekerja yaitu sebagai guru atau dosen, tentara, wiraswasta, buruh, dan dokter; semestinya dapat menyumbangkan keterlibatan yang lebih intensif pada pendidikan anak di TK, yaitu sebagai narasumber berkala di kelas anak, atau sebagai guru sukarela. Hal ini sesuai dengan tipe keterlibatan orangtua menurut Epstein (2002) yang ketiga, yaitu relawan (volunteering). Sayangnya, kegiatan semacam ini belum dilaksanakan di TK-TK tersebut. Namun, keterlibatan orangtua melalui kehadirannya pada berbagai acara di TK (selain sebagai relawan), cukup menggembirakan. Sebagian besar orangtua justru menyempatkan untuk hadir pada puncak tema di TK. Alasan yang disampaikan adalah karena orangtua ingin melihat penampilan anaknya dalam puncak tema tersebut, dan bangga bila anaknya tampil. Sedang keterlibatan orangtua dalam seminar 
pendidikan atau simulasi pengasuhan anak yang diselenggarakan oleh TK belum terlalu tinggi. Kemungkinan kurangnya keterlibatan orangtua dalam hal ini adalah pilihan hari pelaksanaan seminar atau simulasi yang jatuh pada hari kerja sehingga orangtua yang bekerja tidak dapat ikut hadir. Demikian pula dengan guru sukarela, tentunya harus dilaksanakan di hari belajar/hari kerja sehingga jika orangtua bekerja pada instansi tertentu akan sulit hadir kecuali mendapat ijin keluar kantor atau cuti sehari dari pekerjaannya.

Menurut Hornby \& Lafaele (2011), minat orangtua untuk terlibat dalam stimulasi anak juga merupakan salah satu prediktor yang positif terhadap proses dan prestasi belajar anak. Berkaitan dengan pendapat tersebut, salah satu fakta lain yang perlu dilihat adalah tentang keterlibatan orangtua dalam memantau kegiatan anak di rumah. Hal ini juga sesuai dengan tipe keterlibatan orangtua menurut Epstein yang keempat, yaitu belajar di rumah (learning at home). Namun hasil penelitian (Tabel 5) menunjukkan bahwa sebagian orangtua masih bersikap over protektif dalam mengasuh anak, misalnya: masih memandikan anak setiap pagi dan sore, masih menemani anak tidur malam dan anak tidur bersama orangtua sepanjang malam, masih menyuapi anak saat makan, dan masih membantu anak melepaskan dan membuka sepatu.

Jika dirujuk pada model Eipstein khususnya tipe keterlibatan pertama, maka cukup banyak orangtua di Tangerang Selatan yang belum sepenuhnya mampu melakukan tugas keorangtuaan dengan baik, karena masih banyak membantu kegiatan anak sehari-hari di rumah sebagaimana telah dijelaskan di atas. Padahal menurut Montessori, anak usia 4-6 tahun sudah dapat dilatih beberapa hal kecakapan hidup yaitu: (1) toiletris, yaitu kemandirian anak untuk membersihkan diri sendiri yang mencakup: mandi, sikat gigi, berkumur, mengeringkan diri dengan handuk dan meletakkan pakaian kotor ke bak cuci, (2) home service, yaitu kemandirian anak terhadap kebersihan lingkungan tempat tinggal, seperti: menyapu kamar, merapikan mejanya sendiri, mengelap meja, mengelap kaca jendela sendiri, membereskan mainannya, meletakkan sepatu/sandal di rak sepatu, menata alas makannya sendiri, menjamu tamu secara sederhana (misalnya membuatkan teh manis), dan menggunakan telepon; (3) Self service, yaitu pandai bersepeda, memasak snack/makanan ringan, berayun, memakai baju, berenang, memasukkan kancing ke dalam lubang/memakai baju kemeja, meronce sederhana, menjahit sederhana, memakai sepatu dan menalikan sepatu.

Cukup banyak orangtua yang menghendaki anaknya mendapatkan PR dari guru TK-nya. Alasan yang disampaikan orangtua adalah supaya anaknya tidak 'main melulu' tetapi juga belajar dengan cara mengerjakan PR. Pemikiran seperti ini menunjukkan bahwa beberapa orangtua belum memahami tahap-tahap perkembangan anak usia 4-6 tahun, yang masih didominasi bermain. Oleh karena itu cara belajar bagi anak juga bersifat stimulasi dan dilakukan sambil bermain, tidak skolastik dengan memberikan PR. Pada pendidikan TK prinsip ini disebut dengan 'belajar sambil bermain'. Temuan tentang belum pahamnya orangtua ini sesuai dengan data tentang kegiatan anak sehari-hari di rumah (Tabel 6).

Beberapa orangtua yang memutuskan memanggil guru les privat bagi anaknya untuk belajar calistung, belajar bahasa asing ataupun mengerjakan PR di rumah menunjukkan bahwa orangtua belum sepenuhnya memahami tentang usia bermain pada anak-anak, dan belum mampu menjadi fasilitator dan motivator yang baik agar anak dapat belajar di rumah. Oleh karena itu, Epstein (2002) menyatakan bahwa berkaitan dengan tugas keorangtuaan (parenting) dan belajar di rumah (learning at home), maka pihak TK semestinya membantu keluarga dengan berbagai keterampilan yang diperlukan orangtua, karena orang tua di rumah harus mengerti perkembangan anaknya, mengatur suasana rumah agar nyaman bagi anak untuk berkegiatan dan belajar sesuai tingkat usia, sehingga pada gilirannya orangtua akan membantu sekolah dalam memahami berbagai latar belakang budaya orangtua yang berbeda, dan keunikan dari tiap anak yang menjadi teman-teman anaknya.

Selain itu didapatkan data bahwa untuk kegiatan anak sehari-hari di rumah, ternyata kegiatan menonton televisi masih menjadi kegiatan anak yang dominan di rumah, selain kegiatan tidur siang. Baru diikuti kegiatan lainnya yaitu mendengarkan cerita dari buku atau DVD. Khusus untuk kegiatan menonton televisi yang ternyata masih menjadi kegiatan favorit anak-anak di rumah sesuai hasil penelitian di atas, American Academy 
of Pediatrics (AAP) menyarankan agar anak usia 2 tahun ke atas tidak menonton TV lebih dari dua jam sehari. Anak usia di bawah 2 tahun justru tidak direkomendasikan menonton televisi, meskipun acaranya bersifat edukasi.

Pada penelitian ini dapat dilihat bahwa memang sebagian besar anak menonton televisi dari 1 hingga 2 jam saja. Namun ternyata masih ada orangtua yang membiarkan saja anaknya menonton televisi hingga 2-3 jam hingga 3-4 jam, bahkan ada juga yang membiarkan anaknya menonton televisi lebih dari 5 jam, yang artinya keterlibatan orangtua sebagai pengawas anak dalam kegiatan belajar di rumah sangat minim. Penelitian di Amerika Serikat menyatakan bahwa anak di negara tersebut menghabiskan waktu 6.5 jam/hari menggunakan media (AAP, 2007). Kebiasaaan menonton televisi ini sangat perlu dicermati karena pada tahun 2001, The Committee on Public Education of the American Academy of Pediatrics (AAP) mengeluarkan pernyataan bahwa kekerasan di media berdampak pada perilaku kekerasan pada anak setelah menelaah lebih dari 3.500 penelitian.

Berkaitan dengan harapan orangtua pada anak, penelitian yang dilakukan Hoff, Laursen \& Tardiff (2002) menyatakan bahwa orangtua yang pekerjaannya memerlukan keterampilan tidak terlalu khusus dan khusus (semi skilled dan skilled) misalnya: supir, satpam, masinis memiliki harapan pada anak yang berbeda dengan kelompok

\section{PENUTUP}

\section{Kesimpulan}

Beberapa hal yang dapat disimpulkan dari penelitian ini adalah sebagai berikut. Pertama, dilihat dari sisi demografis, yaitu tingkat pendidikan dan status pekerjaan orangtua dari anak usia 4-6 tahun yang berada di TK, orangtua dipandang cukup memiliki potensi untuk banyak terlibat dalam pengasuhan anaknya.

Kedua, keterlibatan orangtua dalam pengasuhan anak di rumah sudah cukup baik karena sebagian besar orangtua telah memperbolehkan anak memilih mainannya sendiri, menuntun anak dalam membaca doa sehari-hari, melatih anak membereskan mainannya, melatih membereskan peralatan makan dan menemani anak saat menonton tv. Namun, orangtua masih perlu diberikan wawasan yang cukup tentang tahap-tahap perkembangan orangtua dari white-collar dan para profesional (dokter, psikolog, dosen, notaris, pengacara, dan lain-lain). Kelompok pertama dikategorikan pada keluarga dengan status sosial ekonomi rendah, biasanya cenderung menekankan kualitas pribadi pada anak berupa kepatuhan, kesopanan, kerapian, kebersihan. Sedang kelompok profesional dikategorikan pada kelompok dengan status sosial ekonomi tinggi, biasanya lebih menekankan pada ciri-ciri (trait) psikologis pada anak seperti: rasa ingin tahu, kebahagiaan, kemampuan mengarahkan diri sendiri, dan kematangan kognitif serta kematangan sosial.

Pada hasil penelitian ini, tampak bahwa harapan terbesar pada anak memang ada pada pencapaian cita-cita, kepatuhan, kerajinan beribadah dan sebagainya yang merupakan ciri khas harapan pada anak dari kelompok orangtua dengan status sosial ekonomi rendah. Hal ini sesuai dengan pendapat dari Hoff, Laursen \& Tardiff (2002) di atas. Responden pada penelitian ini adalah orang tua di TK menengah ke bawah, dan ternyata sebagian besar harapan orangtua berorientasi pada pencapaian cita-cita serta kepatuhan. Orangtua yang mengisi dengan jawaban tersebut sebagian besar adalah bukan dari kaum profesional. Hanya sedikit orangtua yang bekerja di bidang profesional. Namun demikian, harapan tentang kebahagiaan anak juga mendapat porsi yang cukup besar.

anak agar dapat menjalankan tugas keorangtuaan dengan baik, dan mampu menjadi fasilitator kegiatan belajar anak di rumah dengan baik.

Ketiga, keterlibatan orangtua dalam pendidikan anaknya di TK juga sudah cukup baik, terutama dalam hal menjalin komunikasi dengan pihak TK melalui berbagai cara. Sedangkan keterlibatan orang tua sebagai relawan di TK masih perlu ditingkatkan. Saran.

Saran yang dapat diberikan berdasarkan kesimpulan penelitian adalah sebagai berikut. Pertama, pihak TK perlu memikirkan strategi yang sesuai dengan kondisi para orangtua agar keterlibatan orangtua di TK dapat lebih baik, terutama dalam meningkatkan kesukarelawanan.

Kedua, keterlibatan orang tua dalam pengasuhan anak perlu dipertahankan. Namun, 
kemampuan orang tua mengenai tahap-tahap perkembangan anak perlu ditingkatkan. Hal tersebut dapat dilakukan dengan memperbanyak membaca buku tentang parenting. Selain itu, pihak TK juga dapat memberikan wawasan kepada orang tua dengan mengadakan seminar mengenai parenting.

Ketiga, eterlibatan orangtua dalam pendidikan anaknya di TK perlu dipertahankan. Orang tua perlu menjalin komunikasi ke berbagai pihak, baik ke anak, antarsesama orang tua, maupun ke pihak TK. Sedangkan keterlibatan orang tua sebagai relawan di TK masih perlu ditingkatkan. Pihak TK perlu memberikan pengarahan lebih lanjut kepada orang tua agar lebih terlibat dalam kesukarelawanan, seperti pertemuan rutin sebagai ajang berdialog atau berdiskusi

Keempat, perlu dilanjutkan penelitian tentang pengembangan model untuk meningkatkan keterlibatan orang tua dalam pendidikan anak, yang akan mampu meningkatkan keterlibatan orang tua baik di rumah maupun di TK.

\section{DAFTAR PUSTAKA}

American Academy of Pediatrics. (2001). Media Violence. PEDIATRICS Vol. 108 No. 5 November, pp. 1222-1226). http://pediatrics. aappublications.org/content/108/5/1222.full

Arya, P. K. (2008). Rahasia mengasah talenta anak. Yogyakarta: Think

Anonym. (2008). Peran orang tua dalam PAUD. Diunduh dari laman http://paudust.blogspot. com/2008/11/peran-orang-tua-dalam-paud. html

Anonim. Media and children. http://www.aap.org/enus/advocacy-and-policy/aap-health-initiatives/ Pages/Media-and-Children.aspx,

Berk, L. E. (2006). Child development. Boston, Pearson Edu.

Davis-Kean, P. E. (2005). The influence of parent education and family income on child achievement: The indirect role of parental excpectations and the home environment. Journal of Family Psychology, Vol 19, No. 2, 294-304

Englund, M. M., dkk. (2004). Children's achievement in early elementary school: Longitudinal effects of parental involvement, expectations, and quality of assistance. Journal of Educational Psychology, 9(4), 723-730

Epstein, J. L., Sanders, M.G., \& Voorhis F.L. (2002) school, family, and community partnerships: your handbook for action (2nd edition). Corwin, Thousand Oaks, CA.

Fardana, N. A., \& Tairas, M.M.W. (2012). Pengembangan model parental involvement sebagai strategi stimulasi kemampuan literasi pada anak usia 4-6 tahun di wilayah pedesaan Kabupaten Gresik. Jurnal INSAN Unair, Vol. 14 No. 03, Desember 2012
Iskaradah. (2009). Peran orang tua bagi pengembangan anak usia dini. diunduh dari laman http://iskaradah.blogspot.com/2009/05/ peran-orang-tua-bagi-pengembangan-anak. $\mathrm{html}$

Graha, C. (2007). Keberhasilan anak di tangan orangtua. Jakarta: Elex Media Komputindo

Grolnick, W., Benjet, C., Kurowsky, C.O., \& Aostoleris, N.H. (1997). Predictor of parent involvement inchildren's schooling. Journal of Educational Psychology, 89 : 538-548

Henderson \& Mapp. (2002). National Standards for Parent/Family Involvement Programs.

Hayati, N. (2011). Peran orang tua dalam pendidikan anak usia dini. Yogyakarta: UNY. diunduh dari http://staff.uny.ac.id/sites/default/files/tmp/ PPM\%20di\%20TK\%20Pedagogia.pdf

Hoff, Laursen \& Tardiff. (2002). Socioeconomic status \& parenting. Handbook of parenting vol 2. London: Lawrence Erlbaum.

Hornby, G. (2011). Parental involvement in childhood education. London: Springer

Hornby, G. \& Lafaele, R. (2011). Barriers to Parental Involvement in Education: An Explanatory Model. Educational Review. Vol. 63, No.1, February, 37-52

Montessori. Five ways to promote self growth at home, Guelp Montessori School. http:// guelphmontessorischool.ca/2013/08/13/wayspromote-growth-home/

Morrison, G. S. (2008). Fundamentals of early childhood education, 5th ed. New Jersey: Pearson Education, Inc.

Mussen, P. H. (ed), (1970). Handbook of research methods in child development. New Delhi: Wikey Easter Private Ltd 
Profil Keterlibatan Orang ...

Retnaningtyas, M. S. (2015) keterlibatan orangtua dalam pendidikan anak di TKAnak Ceria. Jurnal Psikologi Pendidikan dan Perkembangan, Volume. 4, No. 1, April. Surabaya: Univ Airlangga. h.9-17
Sanderson, S. \& Thompson, V. L. (2002). Factors associated with perceived paternal involvement in childrearing. Sex Roles 46, (3/4), 99-111.

Wong, Dona L, et.al. (2009). Buku ajar keperawatan pediatrik. Jakarta, EGC 